\title{
Wuz Up Wit Dat?: Exploring the Colonizing Properties of the Standard English Language and its Implications for the Denudation and Denigration of Black Survivalist and Stylistic Language, Syntax and Phonology
}

\author{
Buster C. Ogbuagu, Ph.D., M.S.W. \\ College of Arts \& Sciences \\ Department of Social Work \\ University of St. Francis \\ 500 Wilcox Street \\ Joliet, Illinois, 60435, USA \\ Email:bogbuagu@stfrancis.edu
}

Doi:10.5901/ajis/2013.v2n1p135

\begin{abstract}
Black linguistics and ethnolect in America, as a survivalist tool, has existed for over 400 years as a hybridized version of the English and other ethnic languages. This was especially so since Blacks were shackled and forcibly removed from Africa to work the plantation fields of the Americas. Since then its use has metamorphosed into a myriad of languages and sociolets, including lexicon that have been standardized into variants of Pidgin, Creole and others, by Black cultures and communities in America and all over the world. Using theories of racism and anti-oppression resiliency, the study explored the Colonizing properties of the Standard English language and how what is termed Black English language or African American Vernacular English-AAVE in the United States has been used over the millennia to promote esprit de corps and sustain the homeostasis of Blacks and their communities. It also showed how Black English as a survivalist language has suffered a targeted and sustained rejection and threat of extinction from within and without in educational and business institutions, while simultaneously having an ambivalent relationship in music, entertainment and popular culture with mainstream American society. The study presents deconstructionist ramifications for the integration or the lack thereof into mainstream American society of Blacks who use this language at home, in education, work, and civil society, especially due, to the perception that Black English language is ghetto, therefore has no place in or application for upward mobility and mainstream society.
\end{abstract}

Key words: Standard English language, African American Vernacular language-AA VE, Pidgin English, sociolet, ethnolet, syntax, phonology, lexicon, racism, social exclusion, United States, Blacks, African Americans, Whites, White racism, White privilege

\section{Introduction}

Black stylistic language, syntax and phonology have been in existence for over 400 years in Africa, with reference to Nigeria and some parts of the West African sub-region, when the Portuguese first entered around the $14^{\text {th }}$ century (Osamuyimen, 2000; Metz Chapin, I99I). In America, Black language emerged out of the horrors of the Trans-Atlantic Slave Trade that saw hundreds of thousands of Africans shackled and forcibly brought to work the plantations of the Americas and the West Indies. On arrival, the Africans, now slaves, who came from a myriad of ethnicities, languages and cultures, had no way of communicating with one another. It is believed that there were several mutinies and strategies to escape back to Africa, including the Ebo Landing [and the legend of the "Flying Negro] (Powell, 2004), which 
were not feasible if the planners of such great escape could not understand one another. To this extent, the conditions imposed by enslavement forced disparate groups as victims to forge a Pidgin-as in Africa a [Croele in America] form of English language, which the slaves applied in their communication and sustenance. Argues Martinez (2003) Black English evolved as a pot pouri of functional variant of communication, from plantation EnglishCreolization, and transported languages that were used and spoken by African Slaves. He continued, that Black English is a language cross-fertilization internalized and intergenerationally passed in an oral and aural environment and climate. This was mainly due to the Black Codes, as he argued, which attracted not only opprobrium, but severe sanctions of fines and prison for anyone apprehended attempting to inculcate in a slave the art of reading and writing.

Later, even the White slave owners, out of necessity to communicate with their captives were forced to learn Pidgin or Creole, a variant of which is not only currently spoken by Blacks throughout the United States, but also by Whites, especially those resident in the Southern states of the United States (Games, 20II; Patrick, n.d.). The Black slaves, all through the era of the Slave Trade, used Black language primarily to communicate initially and later as agency of survival, esprit de corps, resilience against the horrors of slavery meted out to them by the Whiteman, sustenance of the essence of their culture, cultural values, which they handed down over the generations, knowledge of the world and about who they are and where they came from, expression of their lived experience and the maintenance of their individual and group identity. Suddenly, as a conspiracy theorist would like to believe, the Colonizing properties of the English language, which was the fulcrum for the formation of the Black language in the first instance now feels threatened by Black Vernacular language?

Using psychological theories of racism, and other social identity coordinates, this study explored how systems that are located in governments, organizations, religions, institutions, especially educational institutions, and the American society, individually or collectively, have rendered the Black language and its syntax under an increasing attack. It found that Black vernacular language has not only been ghettoized, but as a ghettoized language, and its users, who are socialized in it, has been rendered unfit for educational and social institutions that assign upward social mobility. It also explored resiliency by how on the other hand, through the paradox of entertainment, music, and the popular culture Black language as a marginalized, ghettoized entity, has become mainstreamed by the same people who jeer at it in formal institutions. These now use it for their aggrandizement because it generates for them a large amount of capital and the appurtenances of financial authority, which they now apply in further marginalizing those [Blacks] on whose backs they climbed to success in the first instance.

\section{Literature Review}

\section{I. Language}

Language constitutes a power tool for communication, teaching, learning and sometimes to control and fringe others in society, who do not have it in their repertoire. In light of this assumption, language posits as a primary agency of communication and interaction, as well as defines how human beings interact with one another, understand one another and assign meaning to utterances and vocalization. Lev Vygotsky's principle was utilized by Gredler (1997) to imply that language stands as the primus amongst the myriad of psychological enablers that mediate thoughts, feelings and behavior. Continuing, Gredler posits that the application of signs and symbols represent the genesis of sociohistorical line of humans, represented and discerned as human speech and written language. In time, the speech and written language become meaningful when they are mastered, internalized and utilized for the organization, regulation and control of social existence. 
A large number of minority groups, when they arrive in the west do not as a norm have and use the English language as their primary language. Many had neither spoken it nor consistently applied it as a communication medium prior to their sojourn in the west. In other cases, English may be their first language, but are spoken with a dialect that may be challenging to discern by those of the dominant or host society, who sometimes fail to perceive it as English language (Abraham and Troike, 1972). Bourdieu (1990a) perceived language more as an instrument of performance of power, and not just and merely for the purposes of communication, which in its pure state language actually is. This power is based on differences that occur on account of race, gender and class identity.

For Ibrahim (2000) the application by Black and African American youth of such parlance as "yoyo," "whassup," "whadap," "homeboy," "talk to the hands," "yo go gal," rap and hip hop, etc., they are "stylistically and lexically allying themselves with, and translating what they conceive as Black linguistic practice" (p.66). Not only that, but Ibrahim also strongly suggested that these Black youths, by the way they speak, the type of lexical, phonological and syntactic choices they make, are also applying this linguistic style, to express and articulate certain identity configurations. Ibrahim further opined that the way Black youths speak, their lexical, phonological and syntactic choices are consistent with the expression and articulation of certain identity properties. Although the dominant culture would like to award a pariah property to the way Black and Black youths use language at home and when with peers, while at school or outside of it, it does not take away from the fact that this language represents in its purest form a genuine expression of desire and identification.

David Miller's book entitled "Citizenship and National Identity" was critiqued by Levinson (2002). Levinson's essay was entitled "Minority Participation and Civic Education in Deliberative Democracies." She argued that for Blacks to be "heard" and understood by the majority population they have to learn, master and adopt the "language of power" which is interpreted as English. Levinson was a teacher of Black students in Boston and Atlanta, where she perceived Black students to be limited or deficient in Standard English vocabulary, contingent on their sustained and exclusive use of Ebonics, African American Vernacular English-AAVE, Black Vernacular English-BVE (Patrick, n.d.) at home and in their communities. Levinson further summed that the lack of exposure to mainstream English implicated the type of schools they attend, TV and movies that they stream and watch, the type of music they listen to and the books and literature they are exposed to. To this extent, Levinson's prescription was Civic education for deliberative democracy that uses the "language of power" ostensibly Standard English, to mainstream Black students into the American society.

Levinson appears to have dabbled into contradictions, when she stated that some other discourses other than mastery of the "language of power" may yet stand in the way of Blacks feeling free to express themselves, honestly and openly without risking misinterpretation of their actual meaning. To this extent, it is quite in order to surmise that the mastery of the "language of power" to the exclusion of other variables represented by power, oppression, and other exclusion discourses falls short of granting Blacks audience by those of the majority population (Berry and Kalin, 2000; Dworkin and Dworkin, 1999; Hochshild, 1995). The sum total of the argument is that Power wielded by Whites as the majority population applies language as a medium to oppress and exclude, rather than language as a single and exclusive variable being culpable. To buttress this assertion, although Black Civil Rights activists such as Dr. Martin Luther King, Malcolm X, Jesse Jackson, Vernon Jordan and Elijah Mohammed all used the "language of power" [King had a Ph.D.], still were not spared the indignities of racial segregation and oppression Contrary to Levinson's genuine but faulty assumptions, mastery of the "language of power(Ogbuagu, 2012) is not the issue because of its inability to confer power on minority groups who are deliberately, systemically and consistently denied it. 


\section{Theoretical Framework}

The theoretical fulcrum for this study is derived from Psychological theories of racism, which main contention sees racism as a form of extreme prejudice, which manifests as the process of social perception. In this, prejudice is perceived as a form of extreme stereotype, and this stereotype, a derivation of the attitude of one individual or group towards another individual or group. Psychological theories of racism present as an ego-defense, contingent upon its ability to bolster or inflate the selfesteem of those who hold them. Psychological theories of racism was popularized by Tajfel and Turner (1986) (see also McLeod, 2008) when they espoused it in terms of Social Identity theory. Social Identity therefore emerges as a result of individuals naturally and constantly striving to maintain their positive self-image through the categorization of (Hogg, 2003) people into In-Groups or Out-Groups, sometimes through the process of racialization (James and Shadd, 200I; Warren and Twine, 1997).

Dixson and Rousseau (2006); Dlamini(2002); Schuman (1975) contend that "selfcondemnation" (p.2I) is the primary culprit in the demoralization of marginalized groups. They state that these marginalized groups and minorities accept and internalize the stereotypical images imposed on them from outside by Whites, prompting them to crawl into their shells, a situation that now provides the dominant group the temerity to gain and perpetuate their own power. Racism is hegemoniously woven into past and modern fabric of powerful societies, especially America (Ogbuagu, 2013) leading to its invisibility, inevitability and invincibility. This situation then renders it arduous to recognize, discuss, challenge and deconstruct. Collins (2000) stated:

To maintain their power, dominant groups create and maintain a popular system of "commonsense" ideas that support their right to rule. In the United States, hegemonic ideologies concerning race, class, gender, sexuality, and nation are often so pervasive that it is difficult to conceptualize alternatives to them (p.284).

Feagin (2000) perceives everyday racism as having a structural dimension, which normalizes and sometimes, justifies racist attitudes.

An ideology is a set of principles and views that embodies the basic interests of a particular social group. Typically, a broad ideology encompasses expressed attitudes and is constantly reflected in the talk and actions of everyday life. One need not know or accept the entire ideology for it to have an impact on thought or action (p.69).

Porter (1965) theory of "Vertical Mosaic," posits that ethnic origins and groups are arranged vertically and applied in the formulation of classes. Those from Northwestern Europe, beginning with Anglo-Saxons represent the apex of this pyramid, while those from Africa were the dregs of society. Ultimately, those in the lower rungs are alienated from capital and the social and economic order (Mensah (2002). Social exclusion uses class and power in its repertoire (Bonnett, 2000; Bulmer \&Solomos, 2004) and since those that are in power are perpetually insecure, they resort to the use of prejudice and discrimination to maintain their status (Simpson and Yinger, 1985). This power, which favors Anglo-Saxons as a "White endeavor" (Myer, 2005, p.20) and according to Heller (1985) and Pinderhughes (1989) becomes internalized owing to centuries old emasculation of Blacks and other minorities. To this extent Whites have created and defined America's history emerging as "White racism" (Feagin\&Hernan, 200I; Feagin, Hernan and Batur, 200I). Feaginet. al. thus defined "White racism" as "the socially organized set of practices, attitudes and ideas that deny African Americans and other people of color the privileges, dignity, opportunities, freedoms, and rewards that this nation offers to White Americans" (p.17). 
The concept of Whiteness argued Harris (2003) is that it is historically and conceptually coterminous with property, which comes with value and rights for humans. One of this right to property is the subjugation and alienation of those regarded as non-equals, particularly Blacks. In attempt to maintain property, Whites also use prejudice, which assists them develop "sincere fictions" (Feagin, Vera, and Batur, 200I, p.26) constructed by individuals or groups, which in turn reproduce myths held about society. In Apartheid South Africa (Foster, 2005) Jan Christiaan Smuts, propagated White European superiority and conversely, African inferiority when he stated:

\title{
Let us hurry to unite the knot and set the good genius of European civilization once more
} free from the bonds, which may strangle her in the future (p.I).

This clarion call, according to Foster, fostered for Whites a siege mentality and became intrinsic in their viewing themselves as an endangered species. Myers (2005) views racism as dialectical, having embedded itself, and operational at the ideological, structural and interactional dimensions. On account of this, racism uses a hierarchical structure to ascertain the distribution of differential opportunities, which pattern then is hegemonized, reproduced and perpetuted when passed through the generations in the socialization process. The hegemonic racism (Bolaria and Li, I988b, 1985) unleashes havoc on the occupants of minority cultures and institutions, while simultaneously embedding inferior and subordinate complex on those it has already ravaged (Milloy, 1999).

For Sullivan (2006) "the shift from de jure to de facto racism corresponds with a related shift from habits of White supremacy to ones of White privilege" (p.5). Sullivan argues further, that it does not take membership into the Ku Klux Klan and Aryan Nation to be identified as a White supremacist. What Sullivan argues as the indices for measuring being defined as such, are transactions with the world in which White domination becomes consciously affirmed and embraced. He argued, that as long as White domination is perpetuated, there will always be, at the micro level of this person, and macro level of society, a mix of White supremacy and White privilege. Sullivan asserted that this mix however, has a higher concentration of unconscious White domination. Sullivan continued:

\begin{abstract}
It is no accident that it is difficult to hear the soft patter of White privilege. White privilege goes to great lengths not to be heard. Habits of White privilege are not merely nonconscious or preconscious. It is not the case that they just happen not to be the object of conscious reflection but could relatively easily become so if only they were drawn to one's attention....It omits the strong resistance to the conscious recognition of racism that characterizes habits of White privilege. As unconscious, habits of White privilege do not merely go unnoticed. They actively thwart the process of conscious reflections on them, which allows them to seem non-existent even as they continue to function (pp. 5-6).
\end{abstract}

Although the effort of critical White studies (Pascale, 2007) is to interrogate, disrupt and discomfit the invisible status of White privilege and Whiteness, there have been uneven outcomes, which appear to sometimes, even serve to recenter, reprivilege and perpetuate the lives and perspectives of White people. Pascale does not lose hope, due to the finding that there are abundant literatures that speak to the social, historical, legal and economic processes, which present vehicles for the deconstruction of a White racial identity.

\section{Methodology}

This is an ethnographic study (Hammersley and Atkinson,1989)which applied qualitative methods to 
explore the issue of the English language as Blacks in the United States understand and use it. The fact of ethnography embeds the use of participant and non-participant observation (Spradley, 1980) which ethnographers have utilized over several decades (DeWalt and DeWalt, 2002)to uncover the lived experiences of people. For Schensul, Schensul and LeCompte (1999) participant observation entails "the process of learning through exposure to or involvement in the day-to-day or routine activities of participants in the researcher setting" (p.9I).

Why use observation? Schmuck (1997) offered that this method assists researchers check and measure nonverbal expressions, including feelings. This then helps to highlight interactional processes and the quality and quantity of time applied in this interactional process. As Schumk further argued, observation for the researcher presents as the vehicle for uncovering definitions of terms explicitly or implicitly applied during interviews, including those events that key informants readily share or those they are hesitant or disinclined to share because it would be insensitive and impolite. In some cases, it may be used to observe events described (Marshall and Rossman, 1995) during interviews by informants, which may assist uncover and make aware any inaccuracies or distortions of the key informants descriptions.

I also used non-participant observation whenever I deemed it pertinent to reduce bias in the study. This strategy presented more challenges, although it was quite possible and productive to be a participant without making disclosures. Non-participant observation presents as means that can be utilized by a researcher, such as Naturalistic observation to observe events and its participants from a distance while not being a part of the activities. In this case, the researcher strives to exert rudimentary impact on the event that they would be surreptitiously observing. Engaging in participant observation has the potential to lead to phenomenological interviews, which evaluates different perspectives, what the meaning and content of an event that those who have experienced them translate them into, without coloring them (Babbie, 2004; Beins, 2004).

The ethnographic method used in this study was enhanced by the information gathered by participant and non-participant observation and a large repertoire of literature, all of which were further triangulated through semi-structured interviews. Pertinent themes (Campbell and Gregor, 2004; Fontana \& Frey, 2000) were highlighted to assist the participants chart a narratives course. The interviews were reduced to analytical materials for the purposes of sifting through and deciphering the meanings cocooned in the transcribed interviews(Kvale and Svend, 2009). Creswell (I998); Wright (2003); Hammersley (2000) all agree on the role and importance of observer integrity regarding the phenomenon, successfully achieved by the application of natural scientific methods, intuition, imagination and universal structures.

In light of the fact that English as a language, and a colonizing one at that has impacted on many cultures across the globe, therefore in a very tangible way helped to inform their lived experience, the 75 participants in this study were randomly drawn from a multiplicity of cultures, languages and ethnicities that have experienced the English language phenomenon. The participants identified themselves as Africans [mainly Nigerians and other West Africans, Asians [comprising the Chinese], and African Americans in the United States, who are the main focus of the study. Most of the participants reside in North America, while a few were residents of Nigeria and other implicated countries in the West African sub-region, which were former colonies of Britain. There were 25 females, while the rest 50 participants were male, for no other reason than that there were more males accessible and willing to participate than females. 45 of the participants were African American owing to their continued involvement in the current language debate and divide. The participants, who were recruited through Key Informants ranged in age from 18 to 70 and expressed having knowledge about the language controversy in their respective countries. All the participants voluntarily agreed to participate and signaled their intention to do so by perusing the Consent form over a number of days and at their 
convenience, and signing and returning them to the researcher. Data collection, using audio recorder and field notes was done over a five year period, owing to the rather large sample size and challenges of accessing the participants.

\section{Emergent Themes}

Several themes emerged from the interviews and interactions with participants. The most pertinent for exploring the subject matter were: English (Pidgin) in African countries, with Nigeria as a case example, English language in China, the controversy surrounding African American Vernacular English-AAVE, "Ebonics," etc. in America-AAVE in the context of school and educational outcomes, Black English language in popular culture, Black English language in American Business, resistance to English language form of colonialism, President Obama's use of Black Vernacular and Standard English.

\section{Discussion}

\section{I. English (Pidgin) in Nigeria and Other post-colonial African countries}

Nigerian [Pidgin] English evolved (Esizimetor and Egbokhare, n.d.; Igboanusi, 2008; Ihemere, 2006; Crozier, 2005; Faraclas, 1996;Shnukel and Marchese, 1983) from its locals trade and other intercourse, first with the Portuguese circa I469, followed by the Dutch and French around I650 and finally the British around the I800s. All these European linguistic groups, during their Nigerian Odyssey left vestiges of their language, all of which influenced the current ways Nigerians speak English. By the time the British consolidated their invasion and occupancy of Nigeria, British English assumed the supplantation of Portuguese as a paramount lexifier of Naijá. The British government on assuming control of Nigeria promptly enforced its English language etiquette on the natives with gusto. I will get to that momentarily. The result was that the Pidgin language not only became very popular with those who struggle with speaking standardized British English, but also spread within big cities multilingual populations. The outcome is that currently in Nigeria, there are more persons who speak Nigerian Pidgin English language as lingua franca than any other. Persons from each of the more than 250 languages (Lewis, Robinson and Rubin; I998; Wente-Luca, 1985) in this British drunken configuration use this medium to communicate.

The British in order to wipe out the vestiges of previous Portuguese, French and Dutch rivaling languages, entrenched English language as the primary and lingua franca of Nigeria in schools and other institutions. According to 33.3 percent representing 25 of the participants from Africa, they were forced as students to use English language especially that referred to as the Queen's English in their education(Whitehead, I98I). Frequently, and as a recipient of the accoutrement of British education I can attest to being physically whipped, forced to perform manual labor and other indignities just for straying into Pidgin English, the local language, Igbo or any Nigerian vernacular. Our education pedagogy consisted of European pedagogy and narratives, especially the waves of Britannia. We studied European History, from the Dark Ages to Oliver Cromwell and the ascendancy of the House of Windsor. Our literature, you guessed it, included English poetry and literature, including Daniel Defoe, Geoffrey Chaucer, all the works of Shakespeare and his escapades with Anna Hathaway of StratfordUpon-Avon, which we also dramatized to good effect or risked severe sanctions. Our rhymes had no cultural context, and can anyone out there explain to me why we should be made to sing "when winter winds are blowing" in the heat and heart of the tropical rain forest, especially when winter did not lexically exist in our social, geographical and cultural repertoire? (Bassey, 1999). 
Currently and due to the corrosive and colonizing properties of the English language, it is a "high crime" in Nigeria to mix tenses or misspeak as people will make a jest of you for gaffing in the English language. How about our children? The participants from Africa, especially Nigerians stated that, having internalized the concept of English language as superior to Igbo, Yoruba, Hausa or Bini, they began and currently still chastise them for attempting to speak any other language but English, and speak it well they must or risk being ridiculed by peers. If they are spared by their peers, they risk their teachers whipping them for making a gaffe in written or spoken English.

Indeed, in Nigeria the fact that one's children can speak English fluently marks their social class and denotes elitism, while speaking vernacular classifies a child as member of a lower socioeconomic class(McLeod, 2008) and no parent wishes that on themselves or children. Therefore parents jumped hoops to ascertain that their children mastered British English and paid a high premium for it by losing their own language, sometimes entirely and completely. The Africans in the study, includingI5 Nigerians, most, of the Baby-Boom era, confirmed with chagrin, the colonizing properties(Dixson and Rousseau, 2006; Dlamini, 2002) of the English language and its impact on their lives. In Nigeria, when children of the educated elite try speaking Igbo or any of the local languages in the presence of their parents, they are hushed with "Don't speak Igbo." Indeed, siblings report themselves to their parents when another speaks the forbidden language. My children who were a part of the participants often query why they are unable to speak Igbo, with my head cowered, I try to provide for them some of the reasons that I have volunteered here.

\subsection{Has the English language also colonized China?}

In the next five years, all state employees younger than 40 will be required to master at least I,OOO English phrases, and all schools will begin teaching English in kindergarten. The government also is funding extensive teacher training programs to find new models for language learning and develop new textbooks (Ward and Francis, 20I0, para.2).

Parents who can afford to, are sending their children -- some as young as 2 -- to private language schools that are popping up all over the country. By the time they are IO, the children will be fluent (para.2).

"China is more open to the world," said one teacher. "We [the older generation] want our kids to open their eyes to get to know the world [and] look at China not only from standing in China but from outside of China as well." (para.3).

State-run TV launched an "American Idol"-type of reality show where kids have to sell themselves in English to clinch the judges' votes (para.4)

Signs in not-quite-right English -- "Car Repairable," "CosmeToulogy" and "Welcom Go Home" -- can be found across the country (para.5).

In light of the above information, the question that needs an answer is whether this is a sign that the English language has also colonized China, with a population of about I.3 billion and with approximately I billion people having Mandarin as the world's most spoken language? The 5 Chinese participants stated that they learned English in China at a significant cost to them prior to their migration to the US. They also admitted that there was a tremendous pressure brought to bear upon students in China to learn and master English, as this was a vehicle for getting good and well-paying 
jobs that Americans siphon to China. What is poignant is that China is the world's most populous nation, extremely wealthy and a US financier, yet, it is pandering to the English culture, represented by its language, English. One Chinese who appeared to understand the discourses of race and "othering" stated:

"I think that China is very important in the world," said one boy. "I wish that American people can speak, can study Chinese. I think that's very good for us to make friends with them" (Ward and Francis, 2010, para.8).

What this shows is that although China is powerful in so many ways, including having a significant trade imbalance with the US that is lop-sided in its favor, its citizens are quite aware that America could care less about them or their language, contingent on their reliance on the social identity theory to remind them how their category is superior to that of the Chinese. Of course, China must learn English, even at the expense of its own language, when English accounts as the common language of business, tourism, technology and the Internet.

\subsection{Black English in America}

\subsection{AAVE in the context of School and Educational outcomes}

The controversy and racial undertones that greet AAVE as a distinct linguistic category did not begin today. However, its controversy-laden properties were amplified and brought to national and international attention in 1996. The hullabaloo occurred, when the Oakland California School Board, dared to want to cater to the needs of an educationally disadvantaged poor city in the San Francisco Bay area, with one half the population being African American. The pronouncement (Wheeler, 1999) was that the board was going to promote successful school outcomes for this population by paying more attention to the languages the students spoke and used at home. Not only this but recognizing it as such and prodding teachers to train to explore it objectively and meritoriously by using it appropriately in the classroom. Led by the New York Times, White media and English language purists immediately, and due to a siege mentality(Giroux, I999) went for the jugular because of their morbid fear that the said linguistic genre not only closely resembled another language presumed to be higher in prestige; it was presumed that AAVE was just a horribly spoken, horribly pronounced nincompoop, grammatically riddled with mistakes as a pollutant version of their cherished prestigious language, English. Indignantly, it was presumed to be saturated with a repertoire of insolent street slang, preferred by ghettoized urban underclass. They did not care if the language was Spanish, Russian or Polish, but a rotten variant of English language? No, they were having none of that, and it would not be in their backyard.

Amidst this feeding frenzy, what got lost was the fact that AAVE is a dialect of English and deserves recognition, respect and acceptance because those who use it in America are bona fide Americans, no less. They have also used it over several hundred years to survive a conspiracy of "othering" (Ogbuagu, 2012; 2013) but poignantly apply it to assist their individual and collective identity, stability and homeostasis. Wheeler (1999) maintains that although AAVE differs markedly from Standard English, it nonetheless and as other languages, contains a degree of regularity and stability attributable to a set of rules of grammar and pronunciation.

Joining the fray, Nieto (I999) opined that Black and minority students are pressured to assimilate as a hidden agenda to discredit cultural and linguistic differences, which in turn promotes, sustains and reproduces inequality. 45 respondents representing 60 percent of the participants were African American, all born and raised in 35 states of the United States. They all were excited to participate in 
the study, especially the burning issue of how they were socialized to speak Black Vernacular English, which to them awarded a sense of belonging about who they actually are, has been under relentless attack. All stated that they had been socialized in school to view their variant of English as ghetto language. They stated that whenever they try speaking it, they are hushed to cease by teachers and sometimes even at home by their parents, for differing reasons. For the teachers who are predominantly White, Black English was a ghetto pollution that should be allowed to expire. For their parents, they fear that a mastery of that language-AAVE is a road to nowhere in America.

Continued Nieto, those who speak a variant of English must shed them quickly on the porch of the school or receive severe sanctions from teachers and peers alike. With time, such minority students begin to show abhorrence for their own language, as represented by the I5 Nigerians in the study, leading to deculturalization (Boateng, 1990). Boateng's deculturalization takes place when those devoid of power are forcibly culturally deracinated. Scott (2000) shared the impact of cultural deracination through linguistic subterfuge:

Janice was in her final practicum of her certification year, and looked forward to her placement because this was the school where she hoped she would be working after graduation. She had particularly asked to work with the special education classes of children who had learning disabilities. One day in her second week, she was asked to assist in the class of children who were labeled "educable mentally retarded." In the group of IO children, there were 2 who did not seem to present the appearance of children with lower intellectual capacity. They were curious and observant, and responded quickly to the teacher's demands, but said very little, and appeared to be very shy. Janice's own curiosity was aroused: what were these children doing in such a class? Later on, in the staff room, the regular teacher told her that these children, two sisters, had recently come from Jamaica, and as no one could understand what they were saying, they were placed in that class (p.68).

The Black or minority student of AAVE is forced to perceive his or her language as unworthy, undesirable, counter-productive and a purveyor of sanctions. Besides, the United States typifies fertile grounds for pressuring ethnic linguistic assimilation, through subtle prohibition of languages other than English, especially in curricular and pedagogical delivery, as Crawford (1992) maintains, eventually excluding them from education and mainstream endeavors. Contrary to linguistic assimilation, Nieto (2000); Zanger (1993); Gibson (I99I) therefore argue that the affirmation and maintenance of cultures and languages of Black and minority students promotes and accelerates successful educational outcomes.

\subsection{Black English language in popular culture}

Since the 1980s and 1990s, there has increasingly developed a racial, ethnic and transcendental use of Black [ghettoized] language for music and entertainment and profit. This cross over was inadvertently engineered by the advent of the likes of MC Hammer, Jay Z, Beyoncé, 50 Cents, Eminem, Lee Iacocca in an ad for Chrysler with Snoop Dogg. Yet, the same language judged as not good enough and found an ambivalent use for upward mobility for white collar business. I will get to this later.

In the 1950s, rock and roll and their rhythm were used and popularized by the products of the Black ghetto language. These were artistes personified by Chuck Berry, Little Richards of the Tutti Frutti fame, Bo Diddley, Ray Charles, Fats Domino, Sam Cooke, James Brown (Kirby, 2008). Soon, some artistes from the majority culture, Elvis Aaron Presley and others perceived the power of music presented by this medium and promptly hijacked it, leading to the reign of rock and roll, classic and 
progressive rock, preponderated by Whites in America, Europe and elsewhere. It was not be long before Black ghetto language saw a resurgence through Rapp, R \& B and Hip-Hop as represented by M C. Hammer [Hammer don't hurt them], Snoop Dogg, Tupak Shakur, Biggie Small, Jay Z, 50 Cents, Puff Daddy, Beyoncé and a host of others. Currently in America, Europe, Africa and the rest of the world, every child and some adults, Black, White, Hispanic, Asian, Green and Blue dabble into listening to and thoroughly enjoying these genre of music and some would willingly lay down their lives for its progenitors. All the participants across race, culture, gender and other variables of difference in this study stated that they knew all the popular culture artistes listed above, listened to most and enjoyed them, except 5 persons, representing approximately 7 percent of the total respondents. This 7 percent have heard of a few of them, but not many. This was accounted for by their immigration to the US from a primarily non-English-speaking country only a few years prior and the fact, as they admitted that they were preoccupied with finding a means of sustenance.

So, the question that needs an answer is, why is this form of Black Vernacular language acceptable even in mainstream American society, but demonized and abhorred in areas, such as educational institutions, where social mobility is gained? As can be seen currently, some White artistes such as Eminem and a few others are into Black language artistry because it is percuniarily profitable and provides popularity and iconhood awarded by a large segment of American society, Africa and Europe who listen to and simply adore it. Who knows how long before it is again hijacked by Whites and mainstreamed for this reason just as in the case of rock and roll?

\subsection{Black English language in Business- Chrysler Corp, Lee Iacocca and Snoop Dogg (what benefit to Black language users?)}

America is a dyed-in-the wool capitalist society and pursuit of enterprise often spurs them to do whatever it takes to maximize profit. In this equation, Lee Iacocca, who was Chrysler Corporation's successful CEO and "savior" by bringing it back from the brink of bankruptcy in the 1980s was known by mainly affluent and well-educated White America (Iacocca, I984). However, and despite his enviable repertoire of achievements, he is a practical unknown among the youth and those who were either not born when he "reigned" or were not mainstreamed in American society. If anything, Lee, an aging White male-88 years[he engineered the Ford Pinto-a disaster and Mustang-a roaring success] (Iacocca, I984)was brilliant, but quite boring. In order to promote sales (Hakim, 2005) Chrysler had to pair up a hip-hop artist from the ghetto and one whose only language was the Black Vernacular language, but very popular among young Americans in a commercial designed to increase sales. "It's a great way to continue to break through the clutter," said Suraya Da Sante, a spokeswoman for the Chrysler Group, a division of DaimlerChrysler, of the commercial. "Snoop is a hip-hop icon, a lot of people know him and recognize him, so it's a fun complement to Lee" (para.5). Asked about the Chrysler, Lee Iacocca and Snoop Dogg commercial only 20 interviewees, representing approximately 27 percentof the respondents admitted or recalled seeing it in 2005. When the researcher pulled the commercial on YouTube, the aha moment came to 40 interviewees or 53.4 percent of the respondents, who had not given a thought to the commercial when they initially saw it. They also had not thought of the implications for the Black language of the commercial, but now saw clearly, the ambivalent relationship that exists between the language and standard English and those who used them.

In strange bedfellowship of Chrysler, Lee Iacocca and Snoop Dogg [actual name Calvin Broadus], Snoop drives up in a Dodge truck and, as he exits from the vehicle, Lee Iacocca interjects

"nice ride." Snoop opens up in his Black [ghetto] linguistic repertoire the only way he knows to speak English, driving off with Lee in the golf cart "Thank you Mocha Cocca. 
Chrysler and Jeep came up on beaucoup awards and Dodge trucks last as long as the D-Odouble gizzle. Plus, I got the hook up nephew, for sure." Puzzled and confused, lacocca mutters: "You know, I'm not too sure what you just said. Now everybody gets a great deal."Snoop continues- "Foshizzle, I-ka-zizzle" (para. 8).

Someone adept at Black language explained the offers and what Snoop was trying to communicate to Lee Iacocca, who obviously was clueless. Even the two men had attires that spoke of their worldsapart difference. Although both men wear pink shirts here, Snoop Dogg wore an argyle sweater embossed with his popular S-D logo;also sports a white hat, sun glasses complemented by checkered white pants and blue. On the other hand, Lee was seen sporting visibly traditional golf attire. The commercial ends with Snoop translating Iacocca's famous tagline-

"if you can find a better car, buy it" (para. I2).

"If the ride is more fly," he says, "then you must buy" (para. I3).

If one reads between the lines, Snoop Dog has no chance in his current incarnation of becoming the CEO of Chrysler or any White-owned or run corporation because he is simply not a good fit due to his only mastery of the English language being Black "ghetto" English and other discourses. On the other hand, corporate America saw a gold mine in him, being a hip-hop icon and one that is by leaps and bounds a much more recognizable face to young persons and American popular culture than Lee Iacocca. Therefore, in Chrysler, corporate America conveniently applied the Machiavellian ethos to its own ends. What mainstream English could not achieve, Black ghetto language accomplished. There lies the ambivalent and strange bed-fellowship between colonizing mainstream or Standardized English and Black [ghettoized] language.

\subsection{New Directions and Milestones}

6.6.I. Forging a less hostile, less ambivalent relationship between mainstream English language and African American Vernacular

It is without question that the demonization of African American Vernacular English, especially its nonacceptance as complimentary to mainstream English stands to push it into extinction. It would be a shame that such language which sustained Blacks and promoted homeostasis of their communities and cultures through several millennia of White emasculation should be allowed to sunset. Not only that, its demonization represents the laying to waste of African American human capital, as the current insistence that AAVE is inferior denies Black youth the opportunity that formal education provides to rise to the height of their potentials. Rather than see AAVE as "primitive" and lacking in ability to spur upward mobility, America and all the other parts of the world that use it should instead see it for what it really is, complementary and a cultural heritage. Italians, British, Greeks, The Irish in America all have and use their vernacular in mainstream American society, and have not experienced a similar stifling of their upward mobility or exclusion as Blacks who use AAVE have. Perhaps, and as stated earlier, it may not necessarily be the language (Levinson, 2002) as it is the race discourse that continues to fringe Blacks in a nation that they disproportionately helped build. On this account, rather than expunging AAVE or Ebonics as some would like to refer toit in the school curricular, an anti-racist and multicultural education (Neito, 2000, 1999) pedagogy may embrace it and competency training for teachers and educators vigorously pursued. All the 45 African Americans in the study would like to see AAVE as a part of the school curriculum, which will appear in tandem with the Standardized English language. In 
support of this trend, Ghosh (2002) opined that the teaching of a second language should not be fashioned to demean and denigrate languages spoken and cultures practiced by minority students. In recognition of this all important discourse and issue confronting teachers on composition and communication on how to respond to the variety in their students' dialects, the Conference on College Composition and Communication (1974) posted the following communiqué:

We affirm the students' rights to patterns and verities of language- the dialects of their nurture or whatever dialects in which they find their own identity and style. Language scholars long ago denied that the myth of a standard American dialect has any validity. The claim that any one dialect is unacceptable amounts to an attempt of one social group to exert its dominance over another. Such a claim leads to false advice for speakers and writers, and immoral advice for humans. A nation proud of its diverse heritage and its cultural and racial variety will preserve its heritage and dialects. We affirm strongly that teachers must have the experiences and training that will enable them to respect diversity and uphold the right of students to their own language

What the CCC is suggesting, which is supported by McLucas (n.d.) is a bidialectal compromise. McLucas strongly argues that prejudice is the main problem that speakers of AAVE confront, because most people, even those from the Black community believe that AAVE is sub-standard to Standard English. For him, as well as what CCC suggests, AAVE has the same legitimacy as American or British English and should not be discounted. One would think that a paradigm shift should have occurred since this statement was made in 1974. However, that time is yet to come for the obvious reason thatlanguage, especially English and other majority cultural languages such as French have hardwired colonizing and imperializing properties, rendering it infeasible to modify the control and domination genes that are embedded in them and the White teachers who preponderate the classrooms (James and Shadd, 200I; Warren and Twine (1997); Dixson and Rousseau (2006); Dlamini (2002); Schuman (1975). Not only this, but the fact that mainstream English is applied to confer a sense of superiority to Whites for whom it is a primary language, and in turn is applied to promote, maintain and reproduce racism and "othering."

\subsubsection{African resistance of English Language colonization}

With the scars of colonialism surreptitiously self-transforming into neo-colonialism, subjects of colonialism appear to be increasingly comprehending its various dimensions and hydra headedness that has allowed it to fester. In this vein, some have even taken steps to deal with Standardized English language for the menace they perceive it to be causing them. Those who still use the English language have chosen to speak and write and apply it in consonance with their culture and ways of doing things. One typical example is Nigeria, where, as soon as one is confronted for mixing tenses or using the socalled flawed English [in relation to how Standard English is used], they would spontaneously retort "It is not my mother tongue and am I Oyinbo (White)?" an allusion to those for whom it is their primary language.

In 1968, the English Language department of the University of Nairobi, Kenya, faculty members agitated for and successfully abolished the English Language department, due to their contention that it was colonizing their thoughts and getting in the way of things (McGee, 1993). The agitators successfully argued that the English language curricular continued to represent and reflect European literary culture and concepts, while it deemphasized and denigrated African cultures and traditions. They argued about the essence of their emancipation from Britain when they still had to be forced to follow their ways of thinking and acting. Argued the "abolitionists," the rustication of English language in the curriculum will provide them with the latitude to design a curriculum that would be appropriately 
consistent with the needs of Africans students and educators in institutions of learning. Ngugi (1972), a renowned writer of African literature surmised:

education is a means of knowledge about ourselves. Politically such knowledge works to reverse colonialism's impact on social construction of African reality: With Africa at the center of things, not existing as an appendix or a satellite of other countries and literatures, things must be seen from the African perspective (p.150).

Many people, especially those that have experienced the colonizing, therefore emasculatory properties of Standard English language can relate to and even agree with Ngugi's measure. However, whereas this divorce and abrogation in somewhat culturally and linguistically homogenous Kenya is feasible, it will be next to impossible in North America for the nearly 50 million Blacks who call here home and have to deal with a majority population that has power, use the language for all its activities of daily living, and all interactions and social networking. Indeed, it will be committing hara-kiri for African Americans to attempt to abolish Standard English language, because they simply have no cultural base in the United States for doing it.

The import of this action and argument underscores the dominating and deracinating properties of English language [language of power and domination] and how it can drive marginalized populations up the wall of anguish and sometimes, irrational thoughts and actions. Another lesson of this measure and its relevance is to underscore the colonizing, therefore, dominating effects of language [language of power]. A more feasible and attractive route would be just what the Oakland, San Francisco Bay area District School Board attempted to accomplish in 1995, which expectedly, but regrettably drew a lot of flak and brouhaha. Still, an effective recommendation would be to seek a solution that will accommodate African American Vernacular English in school and enterprise, thereby protecting the culture and the language that they are socialized into and use everyday of their life. Such a measure stands to also abate or eradicate the ridiculing by mainstream, White America (Gosh, 2002; Nieto, 2000) of Black students' language into which they were socialized. It is important to note that as the demographics in North America shift and the resistance by the majority population remains, it may, and in tandem with language force itself on even the unwilling and unrepentant. Heritage Canada (2000); Moodley (I995); Kubat (I993); Naidoo (I989); Hawkins (1972) expect this paradigm shift to occur with or without the compliance of the majority population, due to the changing demographics of North America as the continent of immigrants.

Another is Bobb-Smith (2003) postulation which perceives racism and racialization of Blacks as a situation that they may not ascribe to, especially the assignment of politicized identity that the oppressor and colonizer has awarded them. To this extent and as Bobb-Smith argued, the marginalized have the capacity to re-examine such identity, redefine, reconstruct or reject them outright. She maintained that oppressions of a subordinating type often present themselves as the cause célébre for the alteration of such identity from a static state, while simultaneously, and as the dynamic object,exerting recalcitrance to effect the desired changes. Bobb-Smith buttresses this argument:

learning to survive is connected to histories of oppressions and to the ways in which communities, subordinated and exploited by hegemonic powers, are sustained...the identities of Caribbean-Canadian women have been constructed to take up a legacy of learning, which has enabled them to produce acts of anti-subordination toward systems of exploitation ( $p .221)$. 
6.6.3. Presidency and Higher political office-Has Black English arrived at the White House and finally America?

Many regard President Barack Obama as the first African American President, a misnomic summation, characterization and identity label that genetically and genealogically falls flat on its face. This is especially so when one factors that his mother, Anne Dunham was Caucasoid, therefore contributed an equal number of the 48 chromosomes required for a fetus to complete its mitosis and emerge as human. Be that as it may, Obama is a product of two worlds-Black and White and others, and it would appear that in this medley of cultures, Obama's use sometimes of AAVE is a strong indication that the Black linguistic culture may not be knelling its last toll but actually evolving and forcing an acceptance in mainstream American society. Alim and Smitherman (20I2) forcefully argued that Obama may have wittingly or unwittingly become a major proponent of the standardization of AAVE linguistics sometime in 2008 post-election Presidential campaign.

They observed that during this time, Obama visited Washington area Ben's Chili Bowl just prior to his inauguration of 2009. Here, when declining to accept the change returned by a Black cashier, Obama retorted "Nah, we straight" (para. 7), a short sentence depicting a poignantly powerful African American way of expression. When prompted, most of the Africans and African Americans-70, comprising 93 percent of the respondents stated having observed President Obama drifting between Black Vernacular language and standardized English. For 45 African Americans in this sample, the fact that Obama routinely speaks their language made them particularly proud, not only of the President, but AAVE as their cultural language and symbol of their identity as Blacks. Those, who had been chided for speaking the language because it was branded ghetto said they now no longer felt ashamed of it as they had previously. The African Americans also stated that they would like AAVE to be taught [and teachers trained in them] in tandem with SEL so that it is not lost to posterity.

Alim and Smitherman also opined that Obama's use of Black language in consonance with hiphop culture, as well as the use of "flow" shows a mapping of rhymes onto a beat. "They're tryna bamboozle you" (para.I2). Obama, as the authors pursued, applied words and phrases not known to be used outside of the Black community and culture, such as "trifling, which means lazy and inadequate and "high-yella" depicting fair-skinned Blacks (para.9). Obama was also described as engaging in zero copula by omitting auxiliaries that join subjects to predicates, a renowned attribute of Black linguistics. Further, Obama's application of speech crescendos and diminuendos embraces pulpit mannerisms and the accompanying prancing associated with Black preachers, such as Dr. Martin Luther King and Malcolm X, depicting the transcendence of Black language into the mainstream fora.
"My opponent and his running mate are ... new ... to foreign policy," he said, adding the two pauses for great comedic effect. The second, and more familiar, was the soaring crescendo, beginning with "in the words of Scripture, ours is a future filled with hope," in which Mr. Obama demonstrated his strongest mode of linguistic performance - the black preacher style - to end his remarks ("knowing that providence is with us and that we are surely blessed") (Alim and Smitherman, 2012, para.I).

To this extent, Obama's flexibility of application merger of White syntax with Black linguistic style has not only established him as an epitome of American identity, but also an avant garde in mainstreaming and unifying American linguistic heritage cultures, be they White, Black or Hispanic. 


\section{Conclusion and directions for future research}

It is increasingly clear that the world as we know it is shrinking and rapidly so into a small village, with multiethnic, multilingual implications that we have absolutely no control over. Obama, in his "Dreams From My Father" stated that he learned Spanish in Harlem in order to communicate with his Puerto Rican neighbors, claimed that his father of Kenyan descent, but as a subject of British imperialism spoke English with a British accent. He learned to speak some Hawaiian Creole himself from his maternal grandfather, and mastered the Indonesian language in less than six months, besides its customs and traditions. Not only that, he has exchanged pleasantries with his Kenyan paternal relatives in the Luo language, and tried signing with the hearing impaired community (as cited in Alim and Smitherman, 2012, para. 17). Pope John Paul II, formerly known as Karol Wojtyla spoke his native Polish in addition to fluent French, German, English, Spanish, Portuguese, Russian, Croatian, Ancient Greek and Latin and, he was none the worse for it, because his horizon widened and he became the most beloved Pope in recent history.

Love it or hate it, Black English linguistic has come to stay, come of age, yet evolving and will come full cycle with or without deliberate human engineering. Certainly its advertent or inadvertent propagation by someone as powerful as President Obama, Chrysler Corp.,Hip-hop and Rapp artistes represented by Snoop Dogg, Eminem and the rest, have serious implications for politics, but more especially, education and poignantly in conscious or unconscious ways signal the genesis of the deconstruction of the myth of Whiteness (Aanerud, 2003; Chabram-Dernersesian, 2003; Muraleedharan, 2003).

In his book, the "Audacity of Hope Obama stated that:

"members of every minority group continue to be measured largely by the degree of our assimilation." But while racial and ethnic minorities (and working-class whites) must continue to learn "standard" American English — the country's dominant language — all children surely need to learn to understand and appreciate the nuances of America's diverse ways of speaking" (as cited in Alim and Smitherman, 2012, para.II).

This statement cannot be more poignant and pragmatic in light of trending facts that show Asians as America's fastest-growing minority and Hispanics as the largest ethnic minority, which means that "we ain't seen nothin yet" as multicultural, multiethnic ways of speaking, thinking, acting and relating are just emerging and will come full cycle in a short time (Warren and Twine, 1997). Alim and Smitherman (2012) could not have put it more aptly when they stated:

"For too long, sounding presidential meant sounding like a white, middle- or upper-class straight man (with modest leeway for regional accents). In 2012 and beyond, it's going to take a lot more than that to win over the hearts and minds - and ears - of the American people" (para.20).

America, you are now officially on notice!

\section{References}

Aanerud, R. (2003). Fictions of Whiteness: Speaking the Names of Whiteness in U.S. Literature. In R. Frankenberg.(Ed.), Displacing Whiteness, (pp.35-59). Durham, NC: Duke University Press. 
Abrahams, R. D.; and Rudolph. C. Troike. (1972). Language \&Cultural Diversity in American Education. New Jersey: Prentice Hall Inc.

Babbie, E. (2004). The Practice of social research. ( $5^{\text {th }}$ Ed.). Belmont, California: Wadsworth Publishing Company.

Bassey, Magnus O. (1999). Western Education and Political Domination in Africa: A Study in Critical and Dialogical Pedagogy.Westport, CT: Bergin \& Garvey.

Beins, B.C. (2004). Research Methods: A Tool for Life. Boston: Pearson/Allyn\& Bacon. Social Psychiatry and Psychiatric Epidemiology 38(I), 35-43.

Berger, Peter. L., and Luckmann, Thomas (1967). The Social Construction of Reality: A Treatise in the Sociology of Knowledge. NY: First Anchor Books Edition.

Blauner, B. (200I). Still the Big News: Racial Oppression in America. Philadelphia: Temple University Press.

Boateng, F. (1990). Combating deculturalization of the African-American child in public school system: A multicultural approach. In K. Lomotey (Ed.), Going to School: The African-American experience (pp.7384). Albany: State University of New York Press.

Bobb-Smith, Y. (2003). I Know Who I Am: A Caribbean Woman's Identity in Canada. Toronto, Ontario: Women's Press.

Bolaria, S. B. \& Peter, S. Li. (I988b).Racial oppression in Canada. Toronto: Garamond Press.

Bolaria, S. B. \& Peter, S. Li. (I985).Racial oppression in Canada.Toronto, Canada: Garamond Press.

Bonnett, A. (2000). Anti-racism. New York: Routledge.

Bourdieu, P. (I990a). Language \& symbolic power.Trans. G. Raymond \& M. Adamson. Oxford: Polity.

Bulmer, Martin and John, Solomos (2004).Researching Race and Racism. Taylor and Francis Group

Campbell, Marie, L., and Gregor, Frances, M. (2004). Mapping Social Relations: A Primer in Doing Institutional Ethnography.Altamira Press.

Chabram-Dernersesian, A. (2003). On the Social Construction of Whiteness Within Selected Chicana/o Discourses.In R. Frankenberg. (Ed.). Displacing Whiteness (pp.I07-I64). Durham, NC: Duke University Press.

Collins, P. H. (2000). Black Feminist Thought, Knowledge, Consciousness, \& the Politics of Empowerment. New York: Routledge.

Conference on College Composition and Communication (CCE) (I974, Fall). Students' Right to Their Own Language.Special Issue of CCC, Vol. XXV. Retrieved January I2, 2013 from http://www.ncte.org/library/NCTEFiles/Groups/CCCC/NewSRTOL.pdf

Crawford, J. (1992). Hold your tongue: Bilingualism \& the politics of "English Only." Reading, MA: AddisonWesley.

Creswell, J. W. (1998). Qualitative Inquiry \& Research Design: Choosing among Five Traditions. London: Sage Publications.

Crozier, David H. (2005). Review of: Nigerian Pidgin in Lagos: Language contact, variation and change in an African urban setting, by Dagmar Deuber. Journal of West African Languages 32, (I-2): I8I-I82.

DeWalt, Kathleen M. \&DeWalt, Billie R. (2002). Participant observation: a guide for fieldworkers. Walnut Creek, CA: AltaMira Press.

Dixson, A.D., and Celia.K. Rousseau. (Eds.) (2006). Critical Race Theory in Education: All God's Children Got a Song. New York: Routledge.

Dlamini, S.N. (2002). From the Other Side of the Desk: Notes on Teaching about Race When Racialized.Race, Ethnicity and Education 5 (I), pp. 5I-56.

Dworkin, A. G. \&Dworkin, R. J. (I999). The Minority report: An introduction to racial, ethnic \& gender relations $\left(3^{\text {rd }}\right.$ Ed.). New York: HarcourtBraceCollege Publishers.

Esizimetor, David, and Egbokhare, Francis (n.d.).Naijá (Nigerian Pidgin). Retrieved January I2, 2013 from http://www.hawaii.edu/satocenter/langnet/definitions/naija.html\#bkgd-hce

Faraclas, Nicholas (1988). Nigerian Pidgin and the Language of Southern Nigeria.Journal of Pidgin and Creole Languages 3: 2, 177-197.

Feagin, J. R. (2000). Racist America: Root, Current Realities, and Future Reparations. New York: Routledge.

Feagin, J. R.\& Vera Hernan (200I). Liberation Sociology. Boulder, CO: Westview.

Feagin, J. R.; Vera, Herman; \&Pina, Batur. (200I). White racism: The Basics.New York\&London: Routledge.

Fontana, A. \& Frey, J. H. (2000). The interview: From structured questions to Negotiated Text. 
In N. K. Denzin.\& Y. S. Lincoln.(Eds.), Handbook of Qualitative Research (pp.645-672). London: Sage Publications, Inc.

Foster, K.M. (2005). Diet of Disparagement: The Racial Experiences of Black Students in a Predominantly White University.International Journal of Qualitative Studies in Education I8 (4), 489-505.

Faraclas, Nicholas C. (1996).Nigerian Pidgin: Descriptive Grammar, Introduction. London: Routledge

Games, Carosene (20II).African American Vernacular English: A Language History Lesson. Retrieved January 9, 2013 fromhttp:/ / carosene.blogspot.com/201 I/II/african-american-vernacular-english.html

Garfinkel, Harold (1967), Studies in Ethnomethodology, Englewood Cliffs, N.J.: Prentice-Hall.

Gibson, M. A. (I99I). Minorities \& schooling: Some implications. In M. A. Gibson \& J. U.

Ogbu (Eds.), Minority status \& schooling: A comparative study of immigrant \& involuntary minorities (pp.35738I). New York: Garland.

Giorgi, Amedeo (1975). "An Application of Phenomenological Method in Psychology," in AmedeoGiorgi, Constance T. Fischer, and Edward L. Murray (Eds.), Duquesne Studies in Phenomenological Psychology: Volume II (pp. 82-I03), Pittsburgh: Duquesne University Press.

Giroux, H. A. (1999). Rewriting the discourse of racial identity: Toward a pedagogy \& politics of Whiteness. In C. Clark \& J. O’Donnel (Eds.), Becoming \& unbecoming White: Owning \& disowning a racial identity (pp.224252). Westport, Connecticut: Bergin \& Garvey.

Ghosh, R. (2002). Redefining multicultural education. (2 ${ }^{\text {nd }}$ Ed.). McGill University, Montreal, Canada: Thomson Learning.

Gredler, M. E. (1997). Chapter I0: Lev. S. Vygotsky'sSociohistorical Theory of Psychological Development.Learning \& Institution: Theory into Practice (3 ${ }^{\text {rd }}$ Ed.). (pp.237-273). Toronto: Prentice-Hall of Canada.

Hakim, Danny (2005, August).Hip-Hop Argot Meets Corporate Cant, All to Sell Chryslers Retrieved January I0, 2013 fromhttp://www.nytimes.com/2005/08/05/automobiles/05auto.html?_r=0

Hammersley, M. and Atkinson, P. (I989).Ethnography principles in practice. London: Routledge.

Hammersley, M. (2000).Taking sides in social research: essays on partisanship and bias. London ; New York : Routledge.

Harris, C. I. (2003). Whiteness as property. In L.M. Alcoff\& E. Mendieta (Eds.), Identities: Race, class, gender \& nationality (pp.75-89). Malden, MA: Blackwell Publishing.

Hawkins, F. (I972). Canada \& immigration: Public policy \& public concern. Montreal, Quebec: McGill-Queen's University Press.

Heritage Canada (2000). Annual report on the operation of the Canadian Multiculturalism Act, I998-I999.

Hochschild, J. L. (I995). Facing up to American dream: Race, class, \& the soul of a nation. Princeton, NJ: Princeton University Press.

Hogg, Michael A. (2003). "Social Categorization, Depersonalization and Group Behavior" In Michael A. Hogg and Scott Tindale (Eds.), Blackwell Handbook of Social Psychology: Group Processes. Malden, MA: Blackwell Publishers, Ltd.

Igboanusi, Herbert (2008). Empowering Nigerian Pidgin: a challenge for status planning?. World Englishes, Vol. 27, No. I, pp. 68-82.

Iacocca, Lee (with William Novak) (1984). Iacocca, an Autobiography. Bantam Books. NY.

Ibrahim, A. (2000). "Whassup homeboy?" Black/popular culture \& the politics of "curriculum studies": In G. J. Sefa Dei \& A. Calliste (Eds.), Power, knowledge \& anti-racism education (pp.57-72). Halifax, Nova Scotia: Fernwood Publishing.

Ihemere, Kelechukwu U. (2006). A Basic Description and Analytic Treatment of Noun Clauses in Nigerian Pidgin. Nordic Journal of African Studies I5, 3: 296-3I3.

James, C. E., \& Adrienne, Shadd. (200I). Talking About Identity: Encounters in Race, Ethnicity, \& Language. Toronto Canada: Between The Lines.

Kirby, David (2008, July/August). The Re-Segregation of Rock \& Roll. The American Interest. Retrieved January I0, 2013 from http://www.the-american-interest.com/article.cfm?piece $=448$

Kubat, D. (I993). The politics of migration policies: Settlement \& integration: The first world into the 1990 s $\left(2^{\text {nd }}\right.$ Ed.). New York: Center for Migration Studies. 
Kvale, Steinar and Brinkmann, Svend (2009). Interviews: Learning the Craft of Qualitative Research Interviews. Thousand Oaks, CA: Sage.

Levinson, M. (2002).Minority participation \& civic education in deliberative democracies. In Avner de-Shalit\& D. Bell (Eds.).Forms of justice.Boulder: Rowman\& Littlefield.

Lewis, M. P., Robinson P. T; \& Rubin B. R. (1998). Stabilizing Nigeria: Sanctions, incentives, \& support for civil society. Sponsored by the Council on Foreign Relations \& The Century Foundation. New York: The Century Foundation Press.

Marger, M. N. (2003).Race \& ethnic relations: American \& global perspectives. (6 ${ }^{\text {th }}$ Ed.). Canada: Thompson Wadsworth Publishing Company.

Marshall, Catherine \&Rossman, Gretchen B. (1995).Designing qualitative research. Newbury Park, CA: Sage.

Martinez, Maurice M. (2003). Black American English: No Child Left Behind. Watson School of Education, UNC Wilmington. Retrieved January 2013 from https://www.google.com/search?q= maurice+martinez+black + american + english

McGee, P. (1993). Decolonization \& the curriculum of English. In C. McCarthy \& W. Crichlow(Eds.). Race, identity \& representation in education (pp.280-288). New York: Routledge.

McLeod, S. A. (2008). Social Identity Theory.Retrieved from http://www.simplypsychology.org/socialidentity-theory.html

McLucas, Bryan (1996). African American Vernacular English.ENG/LIN 404T Project. Retrieved January I2, 2013 from bryan.myweb.uga.edu/AAVE.

Mensah, J. (2002). Black Canadians: History, Experiences, Social Conditions. Halifax: Fernwood Publishing.

Metz Chapin, Helen (Ed.). (I99I).Nigeria: A Country Study. Washington: GPO for the Library of Congress

Milloy, J. S. (1999). A National Crime: Canadian Government and the Residential School System, I879-1986). Winnipeg: University of Manitoba Press.

Moodley, K. A. (1995). The predicament of racial affirmative action.In L. Dreiedger (Ed.). Ethnic Canada: Identities \& inequalities (pp.395-407).

Muraleedharan, T. (2003).Rereading Ghandi.In R. Frankenberg (Ed.).Displacing Whiteness (pp.60-85). Durham, NC: Duke University Press

Myers, K. (2005). Racetalk: Racism Hiding in Plain Sight. Toronto: Rowman\& Littlefield Publishing Inc.

Naidoo, J. C. (I989). Canada's response to racism: Visible minorities in Ontario. Third International Symposium at Oxford: The Refugee Crisis: British \& Canadian Responses. England.

Nieto, S. (2000).Affirming diversity: The Sociopolitical context of multicultural education. White Plains, NY: Longman Publishers.

Nieto, S. (1999). The light in their eyes: Creating multicultural learning communities. Columbia University; New York \& London: Teachers College Press.

NgugiwaThiong'o. (1972). Homecoming: Essays on African and Caribbean literature, culture \& politics. London: Heinemann.

Ogbuagu, B.C. (2013). Constructing America's "New Blacks": Post 9 II Policies and their Impacts on and Implications for the Lived Experiences of Arabs, Muslims and "Others." Mediterranean Journal of Social Sciences Vol. 4 (I), pp.469-480, ISSN 2039-9340

Ogbuagu, B.C (2012). Nice CV! You will hear from us: Canadian labor market and the phenomenology of the marginalized Ethnic professional migrant. Journal of Social Sciences, DOI: I0. 3844/jssp.20I2.I-I2, Vol. 8, Issue I, pp.I-I2. Sage Publications, ISSN I549-3652.

Osamuyimen, Stewart (2000). Nigeria: The Edo of Benin. Retrieved January 10, 2013 from http://www.raceandhistory.com/historicalviews/edoofbenin.htm

Pascale, C. M. (2007). Making Sense of Race, Class, and Gender: Commonsense, Power, and Privilege in the United States. New York \& London: Routledge, Taylor \& Francis Group.

Peter, Patrick L. (n.d.). African American English: A Webpage for Linguists \& Other Folks. Retrieved January II, 2013 from http://privatewww.essex.ac.uk/ patrickp/AAVE.html

Pinderhughes, E. (1989). Understanding race, ethnicity, and power: the key to efficacy in clinical practice. New York: Free Press; London: Collier Macmillan.

Porter, J. A. (1965). The Vertical Mosaic:An Analysis of Social Class \& Power in Canada. Toronto: University of Toronto Press. 
Powell, Timothy B. (2004). Ebos Landing. University of Pennsylvania, Philadelphia. Retrieved January I7, 203 from http://www.georgiaencyclopedia.org/nge/Article.jsp?id=h-2895

Schensul, Stephen L.; Schensul, Jean J. \&LeCompte, Margaret D. (I999). Essential ethnographic methods: observations, interviews, and questionnaires. Walnut Creek, CA: AltaMira Press.

Schmuck, Richard (1997).Practical action research for change. Arlington Heights, IL: IRI/Skylight Training and Publishing.

Shnukal, Anna and LynellMarchese (1983). "Creolization of Nigerian Pidgin English: A Progress Report."English World-wide 4: 17-26.

Schuman, H. (1975).Free will \& determination in public beliefs about race.In Norman. R.Yetman\& C. Hoy Steele (Eds.), Majority \& minority: The dynamics of racial \& ethnic relations (pp.375-380). Boston: Allyn\& Bacon.

Scott, F. B. (200I). Teaching in a multicultural setting: A Canadian perspective. Toronto: Prentice Hall.

Simpson, G. E \&Yinger, M J. (1985).( $5^{\text {th }}$ Ed.). Racial \& cultural minorities: An analysis of prejudice\& discrimination. New York \& London.Plenum Press.

Spradley, J. P. (1980). Participant observation. New York: Holt, Reinhart \& Winston.

Tajfel, Henri and John Turner (1986) 'The Social Identity Theory of Intergroup Behavior', in Stephen Worchel andWilliam G. Austin(Eds.),Psychology of Intergroup Relations, pp. 7-24. Chicago: Nelson-Hall.

Sullivan, S. (2006). Revealing Whiteness: The Unconscious Habits of Racial Privilege. Bloomington and Indianapolis: Indiana University Press.

Warren, J.W., France. W. Twine (1997). "White Americans, the New Minority? Non-Blacks and the EverExpanding Boundaries of Whiteness." Journal of Black Studies 28:200-2I8.

Ward, Clarissa and Francis, Enjoli (2010, November).Ganbei!! China Embraces English Language.Learning English in China. Retrieved January I6, 2013 from http://abcnews.go.com/WN/China/china-pushesenglishlanguage/story? id=I2I54435\#. UOow2GeC-Ps

Wheeler, Rebecca S. (I999) "Home Speech as Springboard to School Speech: Oakland's Commendable Work on Ebonics.”In Rebecca, Wheeler S. (Ed.). The Workings of Language: From Prescriptions to Perspectives (pp. 59-66). New Jersey: Preager.

Wente-Lukas, R. (1985). Handbook of Ethnic Groups in Nigeria.VerlagWeisbaden, Stuttgart: Franz Steiner.

Whitehead, Clive (I98I). 'Education in British Colonial Dependencies, I9I9-39: A Re-Appraisal,' Comparative Education, I7/I (I98I): 72-5.

Wright, C. (2003). Saving the Differences: Essays on Themes from Truth and Objectivity. Cambridge, Mass.: Harvard University Press.

Zanger, V. V. (1993). Academic costs of social marginalization: An analysis of Latino students' perceptions at a Boston high school. In Rivera \&S. Nieto (Eds.).The education of Latino students in Massachusetts: Issues, research, \& policy implications (pp.I67-I87). Boston: Gaston Institute. 